\title{
A Questionnaire of 2020 European Society of Cardiology Atrial Fibrillation Guideline for Cardiologists
}

\author{
(D) Mehmet Özgeyik ${ }^{1}$
}

${ }^{1}$ M.D. Spec., Eskisehir City Hospital, Department of Cardiology, Eskisehir, Turkey

$\ddot{0} z$

Kardiyologlar için 2020 Avrupa Kardiyoloji Cemiyeti Atriyal Fibrilasyon Kılavuzunun Anket Çalıșması

Amaç: Atrial fibrilasyon (AF), en sık görülen klinik önemli kardiyak aritmidir. Klinik pratiğimizde, kardiyoloji alt uzmanlık dalları, akademik unvanları, kılavuzların ilk yayınlandığı günden itibaren okunma süreleri ile ilgili fark olup olmadığına yönelik bir çalışma yapmayı planlandık. Yöntem: Standart bir anket hazırladık ve Türkiye'de bütün kardiyologlara gönderdik. Ankette toplam 27 soru, dört soru AF tanısı, beş soru antikoagülasyon tedavi kararı skoru (CHADS2-VASc ve HAS-BLED), 12 soru AF antikoagülasyonu ile ilgili ve altı soru AF tedavisi ile ilgili olarak gruplanmıștır. İleride yayınlanacak kılavuzlara eklenmesi önerilen üç öznel soru da eklenmiștir.

Bulgular: Bu çalıșmada, 59 kardiyoloji uzmanı ankete katılmıștır. Ortanca yaș 36 (26-52) yıl olarak saptanmıștır ve 50 katılımcının erkek olduğu görülmüștür. Toplam, tanı, antikoagülasyon, tedavi ve antikoagülasyon skorunda bașarılı kiși sayısı sırasıyla 25 (\%42,4), 19 (\%32,2), 30 $(\% 50,8), 19(\% 32,2)$ ve $45(\% 76,3)$ olarak bulunmuştur. Katılımcılar akademik unvanlarına göre gruplanmıștır. Tanı, tedavi, antikoagülasyon ve antikoagülasyon skor soruları doğru cevap oranları, genel sorular hariç gruplar arasında benzer bulunmuștur. Profesörlerin tanı (68,75 puan), antikoagülasyon skoru (75 puan), genel (66,66 puan) soru gruplarında daha bașarılı oldukları, doçentlerin ise antikoagülasyon (71,29 puan) ve tedavi (59,25 puan) soru gruplarında daha başarılı oldukları görülmüștür. Kardiyoloji alt uzmanlık dallarına göre ise toplam, antikoagülasyon ve tedavi soru gruplarında anlamlı fark mevcutken $(p=0.005, p=0.012, p=0.037$, sırasıyla) elektrofizyologlar ve klinik kardiyologlar arasında toplam soruların elektrofizyologlar lehine daha iyi yanıtlandığı $(p=0.005)$ görülmüștür.

Sonuç: Sonuç olarak, 2020 Avrupa Kardiyoloji Cemiyeti AF kılavuzlarının tüm kardiyoloji uzmanları tarafından iyi anlaşıldığı saptanmıştır. Fakat, kardiyolojide önemli bir hastalık olan AF için kılavuz anlașılma oranlarının arttırılması önemlidir.

Anahtar Kelimeler: Atriyal Fibrilasyon, Kılavuz, Kardiyoloji.

\section{Abstract}

\section{A Questionnaire of 2020 European Society of Cardiology Atrial Fibrillation Guideline for Cardiologists}

Objective: Atrial fibrillation (AF) is the most common clinically significant cardiac arrhythmia. In our clinical practice, we wonder any knowledge differences between cardiology subspecialists, academic levels and first reading time interval for guidelines after published.

Methods: A standard questionnaire was created and sent to all cardiology specialists through our country. 27 questions were grouped as total questions (27 questions), AF diagnosis criteria (4 questions), scores of anticoagulation treatment decision (5 questions) (CHADS2-VASc and HASBLED), anticoagulation for AF (12 questions) and AF treatment (6 questions). In addition, 3 subjective questions were asked about the issues that should be included in the next guidelines.

Results: 59 cardiology specialists participated in this survey. Median age was 36 (26-52) years and 50 physicians were male. According to total, diagnosis, anticoagulation, treatment and anticoagulation scores success, 25 (42.4\%), 19 (32.2\%), 30 (50.8\%), 19 (32.2\%) and 45 (76.3\%) participants were successful, respectively. Participants were grouped as academic title. Diagnosis, treatment, anticoagulation and anticoagulation score questions' collected points were not statistically significant different between groups. There was only a statistically significance according to total questions $(\mathrm{p}=0.04)$. Professors were more successful for diagnosis (68.75 points), anticoagulation score (75 points), total (66.66 points) and associate professors were more successful for anticoagulation (71.29 points) and treatment (59.25 points) questions. Cardiology subspecialties were compared according to questions' groups. Total, anticoagulation and treatment questions were statistically significant different between groups ( $p=0.005, p=0.012, p=0.037$, respectively). There was only statistically significance between electrophysiologists and clinic cardiologists according to total questions $(\mathrm{p}=0.005)$ in favor of electrophysiologists.

Conclusion: In conclusion, 2020 ESC AF guideline is well understood among all type of cardiology specialist. However, as AF is one the most important disease in cardiology, general understanding should be increased.

Keywords: Atrial Fibrillation, Guideline, Cardiology.

Nasıl Atıf Yapmalı / How to Cite: Özgeyik M. A Questionnaire of 2020 European Society of Cardiology Atrial Fibrillation Guideline for Cardiologists. MKÜ Tıp Dergisi. 2021;12(43):83-87. https://doi.org/10.17944/mkutfd.919812

Sorumlu Yazar/Corresponding Author: M.D. Spec. Mehmet Özgeyik

Email: mehmetozgeyik@hotmail.com

Geliș/Received: 18 Nisan 2021

ORCID iD: 0000-0002-8510-3505 


\section{INTRODUCTION}

Atrial fibrillation (AF) is the most common clinically significant cardiac arrhythmia. AF is a major cause of mortality and morbidity as well. Stroke risk increases 5-fold with AF and 15\% of all strokes are associated with AF (1). Also, independent of co-morbid conditions, it is associated with a 2-fold risk for allcause mortality (2). In the light of these data, diagnosis and treatment of AF are very significant for clinicians.

Guidelines are very critical to manage major diseases for physicians. European Society of Cardiology (ESC), American Heart Association (AHA) and Canadian Cardiovascular Society (CCS) are the most important communities that publishing AF guidelines regularly. In 2018, CCS released an AF guideline and in 2019, AHA published another AF guideline $(3,4)$. Recently, ESC published the latest $2020 \mathrm{AF}$ guideline (5). Also, the 2020 ESC AF guideline is the longest guideline and we think that its readability is challenging. In our clinical practice, we wonder about any knowledge differences between cardiology subspecialists, academic levels and first reading time interval for guidelines after published. Thus, we conducted this study for cardiology specialists as a questionnaire to evaluate mentioned above.

\section{MATERIALS AND METHODS}

A standard questionnaire was created and sent to 310 cardiology specialists throughout our country, Turkey. This standard questionnaire had 27 objective questions that were prepared by the author according to the 2020 ESC AF guideline. Fifteen questions had two answers, five questions had three answers, three questions had four answers, four questions had five answers and one question had six answers. These questions had only one correct answer according to the 2020 ESC AF guideline. This survey was planned as a quiz at first; however, it was changed as a questionnaire to increase acceptance and understanding by participants. The questionnaire was finished in one round and after answering a question, the participant could not change the answers. In addition, from our point of view, three subjective questions were asked about the issues that should be included in the next guidelines. Only 59 participants completed this survey. Participants of missing answers and giving multiple answers for a question were excluded from this study. Age, sex, academic title, working in cardiology time, cardiology subspecialty, number of patients seen in outpatient clinic per week and first reading time interval for guidelines after published were asked as demographic information. Twenty-seven questions were grouped as total questions (27 questions), AF diagnostic criteria (4 questions), scores of anticoagulation treatment decision (5 questions) (CHADS2-VASC and HAS-BLED), anticoagulation for $\mathrm{AF}$ (12 questions) and AF treatment (6 questions).

All of the physicians were grouped as successful or failed according to question groups (total, diagnosis, anticoagulation, treatment and anticoagulation scores). The success criterion was to collect 60 points (pts) or more. According to the question groups, the percentage at which questions were answered correctly was stated as points. Also, participants were grouped as academic title and cardiology subspecialty. Among these groups, a comparison of statistical significance was performed according to their collected points. All questions and answers were controlled by a cardiology specialist and this specialist did not know the participants' personal information (e.g., name, surname and identity number). Also, all questions were prepared according to guideline higher class of recommendation. In addition, all physicians read the 2020 ESC AF guideline except three participants that were grouped as the first reading time interval for guidelines after published longer than 12 months.

Categorical and continuous data were expressed as the ratio (\%) and mean \pm standard deviation (SD) and they were compared using the chi-square and one-way ANOVA, respectively. Only age parameter was expressed as median and range. If the groups were not homogenous, Welch's One-way ANOVA test was used. After finding statistically significant differences according to one-way ANOVA, post-hoc analyses were performed using Bonferroni or Tamhane's T2 test to compare groups depending on homogeneity. IBM SPSS Statistics for Windows version 23 was used for statistical analyses. P-values $<0.05$ were considered statistically significant.

\section{RESULTS}

The median age was 36 (26-52) years and 50 physicians were male. As academic title, half of the participants were cardiology specialists (54.2\%) and as cardiology subspecialty, 25 participants were electrophysiologists (42.4\%) (Table 1).

All questions were answered completely. According to total, diagnosis, anticoagulation, treatment and anticoagulation scores success, 25 (42.4\%), 19 (32.2\%), 30 (50.8\%), 19 (32.2\%) and 45 (76.3\%) participants were successful, respectively.

Participants were grouped as an academic title. Diagnosis, treatment, anticoagulation and anticoagulation score questions' correct percentage was not statistically significant between groups. There was only a statistically significance according to total questions ( $p=0.04$ ). However, in post-hoc analysis for total questions, there was no statistically significant difference between groups. In addition, professors were more successful for diagnosis (68.75 pts), anticoagulation score (75 pts), total (66.66 pts) and associate professors were more successful for anticoagulation (71.29 pts) and treatment (59.25 pts) questions (Table 2).

Cardiology subspecialties were compared according to 
questions' groups. Diagnosis and anticoagulation score questions were not statistically significant between groups $(p=0.106$ and 0.302 , respectively). However, total, anticoagulation and treatment questions were statistically significant between groups ( $p=0.005, p=0.012, p=0.037$, respectively) (Table 3). Bonferroni test was used to compare subspecialties. There was only statistically significance between electrophysiologists and clinic cardiologists according to total questions $(p=0.005)$ in favor of electrophysiologists.

Table 1. Baseline demographies and number of the study population according to success criterion

\begin{tabular}{|c|c|c|c|}
\hline & Successful (n) & Failed (n) & Total (n) \\
\hline $\begin{array}{c}\text { Sex } \\
\text { Male } \\
\text { Female }\end{array}$ & $\begin{array}{c}21(35.6 \%) \\
4(6.8 \%)\end{array}$ & $\begin{array}{c}29(49.2 \%) \\
5(8.5 \%)\end{array}$ & $\begin{array}{c}50(84.7 \%) \\
9(15.3 \%)\end{array}$ \\
\hline $\begin{array}{l}\text { Academic Title } \\
\text { Assistant } \\
\text { Specialist } \\
\text { Assistant Prof. } \\
\text { Associate Prof. } \\
\text { Professor }\end{array}$ & $\begin{array}{c}1(1.7 \%) \\
10(16.9 \%) \\
5(8.5 \%) \\
7(11.9 \%) \\
2(3.4 \%)\end{array}$ & $\begin{array}{c}4(6.8 \%) \\
22(37.3 \%) \\
4(6.8 \%) \\
2(3.4 \%) \\
2(3.4 \%)\end{array}$ & $\begin{array}{c}5(8.5 \%) \\
32(54.2 \%) \\
9(15.3 \%) \\
9(15.3 \%) \\
4(6.8 \%)\end{array}$ \\
\hline $\begin{array}{l}\text { Time in Cardiology } \\
\text { Practice } \\
0-6 \text { years } \\
6-10 \text { years } \\
10-15 \text { years } \\
>15 \text { years }\end{array}$ & $\begin{array}{c}4(6.8 \%) \\
6(10.2 \%) \\
10(16.9 \%) \\
5(8.5 \%)\end{array}$ & $\begin{array}{c}14(23.7 \%) \\
8(13.5 \%) \\
8(13.6 \%) \\
4(6.8 \%)\end{array}$ & $\begin{array}{c}18(30.5 \%) \\
14(23.7 \%) \\
18(30.5 \%) \\
9(15.3 \%)\end{array}$ \\
\hline $\begin{array}{l}\text { Subspecialty of Cardiology } \\
\text { Electro-physiologist } \\
\text { Invasive } \\
\text { Imaging } \\
\text { Clinic }\end{array}$ & $\begin{array}{c}15(25.4 \%) \\
6(10.2 \%) \\
3(5.1 \%) \\
1(1.7 \%)\end{array}$ & $\begin{array}{c}10(16.9 \%) \\
11(18.6 \%) \\
4(6.8 \%) \\
9(15.3 \%)\end{array}$ & $\begin{array}{c}25(42.4 \%) \\
17(28.8 \%) \\
7(11.9 \%) \\
10(16.9 \%)\end{array}$ \\
\hline $\begin{array}{l}\text { Time to the first reading of } \\
\text { guidelines after published } \\
\begin{array}{c}0-1 \text { month } \\
1-3 \text { months } \\
3-6 \text { months } \\
6-12 \text { months } \\
>12 \text { months }\end{array}\end{array}$ & $\begin{array}{c}12(20.3 \%) \\
11(18.6 \%) \\
1(1.7 \%) \\
1(1.7 \%) \\
0\end{array}$ & $\begin{array}{c}7(11.9 \%) \\
14(23.7 \%) \\
6(10.2 \%) \\
4(6.8 \%) \\
3(5.1 \%)\end{array}$ & $\begin{array}{c}19(32.2 \%) \\
25(42.4 \%) \\
7(11.9 \%) \\
5(8.5 \%) \\
3(5.1 \%)\end{array}$ \\
\hline $\begin{array}{c}\text { Number of patients per } \\
\text { week } \\
\text { 0-50 patients } \\
\text { 50-100 patients } \\
\text { 100-150 patients } \\
\text { 150-200 patients } \\
>200 \text { patients }\end{array}$ & $\begin{array}{c}5(8.5 \%) \\
3(5.1 \%) \\
10(16.9 \%) \\
4(6.8 \%) \\
3(5.1 \%)\end{array}$ & $\begin{array}{c}2(3.4 \%) \\
6(10.2 \%) \\
13(22 \%) \\
4(6.8 \%) \\
9(15.3 \%)\end{array}$ & $\begin{array}{c}7(11.9 \%) \\
9(15.3 \%) \\
23(39 \%) \\
8(13.6 \%) \\
12(20.3 \%)\end{array}$ \\
\hline
\end{tabular}

The first reading time intervals for guidelines after published were compared according to questions' groups. Treat- ment and anticoagulation questions were not statistically significant between groups ( $p=0.193$ and $p=0.064$, respectively). However, diagnosis and anticoagulation score questions were statistically significant between groups ( $p=0.001$, $p=0.017, p=0.039$, respectively) (Table 4). Bonferroni test was used to compare groups. There was only statistically significance between 0-1 month and beyond 12 months according to total questions $(p=0.001)$ in favor of $0-1$ month. In addition, 0-1month time interval group had a higher point for all questions' groups except the treatment questions group (Diagnosis 61.84 pts, anticoagulation score 73.68 pts, anticoagulation 68.42 pts, total 64.91 pts).

\begin{tabular}{|c|c|c|c|c|c|c|}
\hline & Assistant (pts) & Specialist (pts) & $\begin{array}{c}\text { Assistant } \\
\text { Professor } \\
\text { (pts) }\end{array}$ & $\begin{array}{c}\text { Associated } \\
\text { Professor (pts) }\end{array}$ & Professor (pts) & $p$ \\
\hline Diagnosis & $25 \pm 17.67$ & $46.87 \pm 27.49$ & $58.33 \pm 25$ & $55.55 \pm 34.86$ & $68.75 \pm 31.45$ & 0.137 \\
\hline Treatment & $43.33 \pm 19$ & $46.35 \pm 17.82$ & $50 \pm 18.63$ & $59.25 \pm 20.6$ & $54.16 \pm 15.95$ & 0.380 \\
\hline Anticoagulation & $63.33 \pm 12.63$ & $62.23 \pm 14.66$ & $59.25 \pm 13.46$ & $71.29 \pm 8.44$ & $68.75 \pm 15.77$ & 0.337 \\
\hline $\begin{array}{l}\text { Anticoagulation } \\
\text { Score }\end{array}$ & $44 \pm 16.73$ & $63.75 \pm 20.59$ & $64.44 \pm 19.43$ & $68.88 \pm 20.27$ & $75 \pm 19.14$ & 0.168 \\
\hline Total & $49.62 \pm 8.11$ & $56.71 \pm 10.78$ & $58.02 \pm 11.41$ & $65.84 \pm 10.76$ & $66.66 \pm 11.71$ & 0.04 \\
\hline
\end{tabular}

Table 3. Collected points of the questions groups according to cardiology subspecialties

\begin{tabular}{|c|c|c|c|c|c|}
\hline & $\begin{array}{c}\text { Electrophysiologist } \\
\text { (pts) }\end{array}$ & $\begin{array}{c}\text { Invasive } \\
\text { Cardiologist } \\
\text { (pts) }\end{array}$ & $\begin{array}{c}\text { Imaging } \\
\text { Cardiologist } \\
\text { (pts) }\end{array}$ & $\begin{array}{c}\text { Clinic } \\
\text { Cardiologist } \\
(\mathbf{p t s})\end{array}$ & $\mathbf{p}$ \\
\hline Diagnosis & $53 \pm 31.72$ & $45.58 \pm 25.36$ & $67.85 \pm 18.89$ & $35 \pm 26.87$ & 0.106 \\
\hline Treatment & $55.33 \pm 16.47$ & $50 \pm 20.41$ & $35.71 \pm 11.5$ & $41.66 \pm 18$ & 0.037 \\
\hline Anticoagulation & $66 \pm 13.15$ & $63.23 \pm 11.04$ & $72.61 \pm 13.36$ & $52.5 \pm 14.19$ & 0.012 \\
\hline Anticoagulation & $67.2 \pm 19.89$ & $60 \pm 21.21$ & $71.42 \pm 19.51$ & $56 \pm 20.65$ & 0.302 \\
\hline Score & $61.92 \pm 12.12$ & $57.08 \pm 7.29$ & $63.49 \pm 7.83$ & $48.14 \pm 11.44$ & 0.005 \\
\hline Total & & &
\end{tabular}

\section{DISCUSSION}

Atrial fibrillation is a very important disease as it has extensive morbidity and mortality. Therefore, AF diagnosis, treatment and guideline understanding are very significant for physicians. In this study, we compared cardiologists' subspecialty, academic title and guideline first reading time interval. In a general perspective, there were no statistically significant differences between groups. However, there are some significant issues that should be mentioned.

AF is a rhythm disorder and generally seen as an electrophysiologist's field of interest. Most AF studies have been conducted by electrophysiologists so far (6-8). However, in clinical practice, all of the physicians come across with AF frequently, so management of AF is crucial for all. In this study, there was only a statistically significance between electrophysiologists and clinical cardiologists according to total questions. This 
was attributed to low academic level among clinical cardiologists because increasing academic level come across with much more reading. In addition, subheadings of the guideline were considered, and there was no statistically significant difference between groups. In-depth understanding among a wide spectrum of physicians is a good situation; however, all subspecialties' understanding of AF should be increased in the next generation guidelines.

\begin{tabular}{|c|c|c|c|c|c|c|}
\hline & $\begin{array}{c}\text { 0-1 month } \\
\text { (pts) }\end{array}$ & $\begin{array}{l}1-3 \text { months } \\
\text { (pts) }\end{array}$ & $\begin{array}{l}\text { 3-6 months } \\
\text { (pts) }\end{array}$ & $\begin{array}{l}\text { 6-12 months } \\
\text { (pts) }\end{array}$ & $\begin{array}{c}>12 \text { months } \\
\text { (pts) }\end{array}$ & $p$ \\
\hline Diagnosis & $61.84 \pm 26.83$ & $52 \pm 27.87$ & $35.71 \pm 19.66$ & $30 \pm 27.38$ & $16.66 \pm 28.86$ & 0.017 \\
\hline Treatment & $52.63 \pm 17.97$ & $44.66 \pm 17.82$ & $50 \pm 21.51$ & $63.33 \pm 13.94$ & $38.88 \pm 19.24$ & 0.193 \\
\hline Anticoagulation & $68.42 \pm 12.9$ & $64.66 \pm 15.07$ & $59.52 \pm 7.49$ & $56.66 \pm 9.12$ & $47.22 \pm 9.62$ & 0.064 \\
\hline $\begin{array}{l}\text { Anticoagulation } \\
\text { Score }\end{array}$ & $73.68 \pm 16.4$ & $60.8 \pm 16.81$ & $57.14 \pm 31.47$ & $64 \pm 21.9$ & $40 \pm 20$ & 0.039 \\
\hline Total & $64.91 \pm 11.2$ & $57.62 \pm 9.8$ & $53.43 \pm 8.51$ & $55.55 \pm 7.4$ & $39.5 \pm 9.32$ & 0.001 \\
\hline
\end{tabular}

The academic level is another significant determinant for guideline knowledge. According to all questions groups, there was no statistically significant difference between academic titles as collected points. However, assistants had lower points than others. On the other hand, associated professors and professors had higher points. This can be explained by two situations. Newly published guidelines build on previous ones. Therefore, reading the previous guidelines makes it easier to understand the new ones. Secondly, clinical practice helps physicians to understand medical knowledge easily. Hence, the longer you work in a clinic, the better you understand what you read.

2020 ESC AF guideline is the longest guideline ever published in the history of ESC (Main text is the page between eight and 84) (5). In this study, physicians collected 58.3 points according to total questions. In addition, the diagnosis, anticoagulation scores, anticoagulation and treatment parts contain 16, 4, 7 and 19 pages, respectively. In this study, all physicians' collected points were 49.5, 63.7, 63.7 and 49.1 for diagnosis, anticoagulation scores, anticoagulation and treatment groups, respectively. As seen, there was a negative correlation between text length and success points. In a previous study, researchers underlined that text length affects the understanding of English language learners (9). Thus, giving spot data and a bit shortening of next guidelines may be appropriate for well understanding as all physicians' native language is not English worldwide.

In this questionnaire, three additional subjective questions were asked to participants. The first question was, "Is there any additional parameters or dosage measurements necessity for new oral anticoagulants (NOAC)?' Anti-Xa activity and diluted thrombin time show NOAC's activity indirect- ly (10). This question was prepared according to a practical guide (11). More than half of the participants agreed to the necessity of additional measurements (55.9\%). There was an interesting comparison between an electrophysiologist and an invasive cardiologist. Most of the electrophysiologists did not agree with this question (64\%). On the other hand, invasive cardiologists thought that there was a necessity for additional measurements (94.1\%), and there was a statistically significant difference. The second question was about the physician's approach if the thrombus persists in the left atrial appendix (LAA) after three weeks of oral anticoagulation (OAC) treatment. Most of the participants (81.4\%) delay the cardioversion or ablation procedures and then reconsider again later. However, there was no consensus among participants on this situation. The third question was about the comparison of rhythm and rate control for primary end-points. In the literature, there was no consensus on this issue. Marrouche et al. found that catheter ablation offers a mortality benefit against medical therapy for heart failure patients; however, Kong et al. have claimed that there is no mortality benefit for rhythm control against rate control among diastolic heart failure patients $(12,13)$. In this study, most participants have thought that subtypes of AF affect the treatment strategy and primary end-points would be better in favor of rhythm control if AF subtypes were considered (64.4\%). In addition, there was no statistically significant difference among cardiology subspecialties and academic title for this question ( $p=0.127$, $p=0.935$, respectively, one-way ANOVA). In the light of these three questions, next-generation AF guidelines should comprise these issues to prevent conflict among physicians.

In conclusion, the 2020 ESC AF guideline is well understood among all types of cardiology specialists. There was no statistically significant difference among cardiology subspecialties and academic titles. However, as AF is one of the most significant diseases in cardiology, general understanding should be increased. In addition, in the next guidelines, some issues should be clarified that are mentioned in this study as subjective questions.

\section{Limitations}

This study has limitations that should be considered. Firstly, 59 cardiology specialists participated in this questionnaire. In further studies, more participants should be included. Secondly, this study only takes place in Turkey, and multinational studies may provide more significant results. Thirdly, ESC 2020 AF guideline was written in the English language, so understanding relies on participants' English level. In this study, participants' English level was unknown, and in further studies, an objective English level meter among participants may be added. Finally, one cardiology specialist prepared this questionnaire. In further studies, a cardiology specialist council may prepare the questionnaire, 
which can provide us with more reliable results.

\section{ACKNOWLEDGEMENT}

Peer-Review

Externally Peer Reviewed

Conflict of Interest

The authors declare that they have no conflict of interests regarding content of this article.

Financial Support

The Authors report no financial support regarding content of this article.

Ethical Declaration

Helsinki Declaration rules were followed to conduct this study and no ethical approval is need for this study.

\section{REFERENCES}

1. Hart RG, Benavente 0 , McBride R, Pearce LA. Antithrombotic therapy to prevent stroke in patients with atrial fibrillation: a meta-analysis. Annals of internal medicine. 1999;131(7):492-501. https://doi. org/10.7326/0003-4819-131-7-199910050-00003

2. Benjamin EJ, Wolf PA, D'Agostino RB, Silbershatz H, Kannel WB, Levy D. Impact of atrial fibrillation on the risk of death: the Framingham Heart Study. Circulation. 1998;98(10):946-52.

https://doi.org/10.1161/01. cir.98.10.946

3. Andrade JG, Verma A, Mitchell LB, Parkash R, Leblanc K, Atzema C, et al. 2018 focused update of the Canadian Cardiovascular Society guidelines for the management of atrial fibrillation. Canadian Journal of Cardiology. 2018;34(11):1371-92. https://doi.org/10.1016/j. cjca.2018.08.026

4. January CT, Wann LS, Calkins H, Chen LY, Cigarroa JE, Cleveland JC, et al. 2019 AHA/ACC/HRS focused update of the 2014 AHA/ACC/HRS guideline for the management of patients with atrial fibrillation: a report of the American College of Cardiology/American Heart Association Task Force on Clinical Practice Guidelines and the Heart Rhythm Society. Journal of the American College of Cardiology. 2019;74(1):104-32. https://doi. org/10.1016/j.jacc.2019.01.011

5. Hindricks G, Potpara T, Dagres N, Arbelo E, Bax JJ, Blomstro C, et al. 2020 ESC Guidelines for the diagnosis and management of atrial fibrillation developed in collaboration with the European Association of CardioThoracic Surgery (EACTS). European heart journal. 2020. 1;42(5):373-498. https://doi.org/10.1093/eurheartj/ ehaa612
6. Packer DL, Mark DB, Robb RA, Monahan KH, Bahnson TD, Poole JE, et al. Effect of Catheter Ablation vs Antiarrhythmic Drug Therapy on Mortality, Stroke, Bleeding, and Cardiac Arrest Among Patients With Atrial Fibrillation: The CABANA Randomized Clinical Trial. Jama. 2019;321(13):1261-74. https://doi.org/10.1001/ jama.2019.0693

7. Kuck KH, Merkely B, Zahn R, Arentz T, Seidl K, Schlüter M, et al. Catheter Ablation Versus Best Medical Therapy in Patients With Persistent Atrial Fibrillation and Congestive Heart Failure: The Randomized AMICA Trial. Circulation Arrhythmia and electrophysiology. 2019;12(12):e007731. https://doi.org/10.1161/CIRCEP.119.007731

8. Cosedis Nielsen J, Johannessen A, Raatikainen $P$, Hindricks $G$, Walfridsson $H$, Kongstad 0 , et al. Radiofrequency ablation as initial therapy in paroxysmal atrial fibrillation. The New England journal of medicine. 2012;367(17):1587-95. https://doi.org/10.1056/ NEJMoa1113566

9. Far M-T. The effects of text type, text length and text difficulty on vocabulary retention through glossing. The Journal of Language Learning and Teaching. 2016;6(1):90-104

10. Nowak H, Unterberg M. (Oral Anticoagulants: Management of Elective and Emergency Surgery). Anasthesiologie, Intensivmedizin, Notfallmedizin, Schmerztherapie : AINS. 2018;53(7-08):543-50. https:// doi.org/10.1055/s-0043-111006

11. Steffel J, Verhamme P, Potpara TS, Albaladejo P, Antz M, Desteghe L, et al. The 2018 European Heart Rhythm Association Practical Guide on the use of non-vitamin $\mathrm{K}$ antagonist oral anticoagulants in patients with atrial fibrillation. Eur Heart J. 2018;39(16):1330-93. https:// doi.org/10.1093/eurheartj/ehy136

12. Marrouche NF, Brachmann J, Andresen D, Siebels J, Boersma L, Jordaens L, et al. Catheter Ablation for Atrial Fibrillation with Heart Failure. The New England journal of medicine. 2018;378(5):417-27. https://doi. org/10.1056/NEJMoa1707855

13. Kong MH, Shaw LK, O'Connor C, Califf RM, Blazing MA, Al-Khatib SM. Is rhythm-control superior to rate-control in patients with atrial fibrillation and diastolic heart failure? Annals of noninvasive electrocardiology: the official journal of the International Society for Holter and Noninvasive Electrocardiology, Inc. 2010;15(3):20917. https://doi.org/10.1111/j.1542-474X.2010.00365.x 